МРНТИ 14.07.03

DOI 10.47649/vau.2021.v61.i2.04

УДК 37.03

\author{
S. Karabalina ${ }^{*}$ (D), A. Tleuova ${ }^{2}$ \\ ${ }^{1}$ Kh.Dosmukhamedov Atyrau university \\ Atyrau, 060011, Kazakhstan \\ *e-mail: s.karabalina@asu.edu.kz
}

\title{
FORMATION AND DEVELOPMENT OF INTELLECTUAL POTENTIAL OF UNIVERSITY STUDENTS
}

This article focuses on the main task of strengthening national values - the modernization, informatization, further development of education, the development of intelligence, the formation of continuing education.

The issue formation of the intellectual potential nation has been widely studied, considered, the main indicators are indicated. The formation of a competitive personality in line with modern requirements is accompanied by economic, social and political prosperity of the country.

Information technology is developing rapidly, attitudes to education are changing, the world has changed. Today's approach to education has been updated and is still in the spotlight. We consider the education system not only as an education, but as a social phenomenon that contributes to the formation and development of the individual.

The main task today is to improve the quality of education for school and university graduates. The main task is to develop the individual, to adapt to the environment - to cope with the current economic crisis, change and become a competitive person in this environment.

Therefore, we know that the modernization of the structure of education in the country is the main mechanism for ensuring the civilized development of our modern society.

Modernization of the entire structure of education, ensuring the competitiveness of Kazakhstan, is the main mechanism for ensuring the civilized development of modern society.

The education system is not only a pedagogical category, but also a social phenomenon that has a huge impact on the development of human capital.

Key words: intellectual nation, eternal country, individuality, modernization, intellectual potential.

\section{Introduction}

\section{The background and the aim of the research}

The basic definitions that determine the formation of the intellectual personality of students are the concepts of "intelligence", "intellectual potential of the person", "intellectual personality", "intellectual nation". Intelligence, memory, understanding, cognition - the highest category of thinking. Intellectual - the ability to read, acquire knowledge, self-improvement in practice, to adapt and use it for self-development and the development of society, the qualities of nature, such as thought, consciousness, cognition, intellect, reason. An intellectual person is a person who is able to fully express his thoughts in any flow of life, is prone to self-information, education, and has great intellectual abilities. [7;p 616]

An intellectual potential person is an individual who is able to use the knowledge, skills and competencies that have emerged through a high level of mastery of new and specialized sources of knowledge based on moral and national values in the interests of himself, his nation and his homeland. $[1 ; \mathrm{p} 40]$

In determining the theoretical basis for the formation of the nation's intelligence, the main indicators of the intellectual nation are reflected through the study of actions accumulated in international experience, especially the principles and principles set out in the UN documents. [2; $p$ 5-27]

Information technology is developing rapidly, attitudes to education are changing, the world has changed. Today's approach to education has been updated and is still in the spotlight. 
It is known that in the development of each epoch, in the study of the ancient history of the Kazakh people, the development and formation of a strong, rich country with a spirit, a proud personality, was a topical issue for every leader. Therefore, the professional development of the future specialist is very important in today's society, especially in the provision of updated, innovative information, the formation of a competitive personality. In all ages, the teacher was considered an intelligent community, an intelligent generation. [5; $\mathrm{p} 10]$

In preserving the independence and sovereignty of the country, the organization of harmony and unity in society, the formation of an intelligent society lies at the height of professional competence, knowledge and skills, the spirit of the future specialist. [6; $\mathrm{p} 21]$

University is the main environment for the formation of intellectual personality. The integration of the higher education system into the global educational space, the high level of mastery information technology by students shows a breakthrough in the social process.

The main ways of forming and developing the intellectual potential of university students: teaching, educational process, educational environment: lectures, seminars, student work under the guidance of a teacher, student independent work, debates, group work, scientific and practical student conferences, round tables, higher education scientific, educational and methodical centers and out-ofuniversity cultural centers, museums, etc. can be called. In the formation of the intellectual potential of the student, it was found in the course of experimental work that the development of the student's personality, self-search, improvement of knowledge, etc.

Methods of brainstorming, heuristic conversation, debate, "role play", etc. in the formation of intellectual potential of students contribute to the development of cognitive thinking, the development of mental and other abilities.

\begin{tabular}{|c|c|c|}
\hline № & Types of intelligence & Criteria \\
\hline 1 & Social intelligence & $\begin{array}{l}\text { interpersonal relationships, age differences, } \\
\text { behavior in the social environment. }\end{array}$ \\
\hline 2 & Genetically, intelligence & man - society - man; man - nature - society - man. \\
\hline 3 & Procedural intelligence & $\begin{array}{l}\text { critical thinking, breadth of thought, development of } \\
\text { intuition. }\end{array}$ \\
\hline 4 & $\begin{array}{l}\text { Phenomenological } \\
\text { intelligence }\end{array}$ & $\begin{array}{l}\text { logical thinking, accuracy of thinking, the } \\
\text { development of intuition is a special form of } \\
\text { cognition, the content of consciousness. }\end{array}$ \\
\hline 5 & $\begin{array}{l}\text { From the structural-level } \\
\text { point of view }\end{array}$ & $\begin{array}{l}\text { the depth of the mind, the speed of thought, the } \\
\text { breadth of thought, the system of cognitive } \\
\text { processes at different levels. }\end{array}$ \\
\hline 6 & Regulatory intelligence & $\begin{array}{l}\text { the ability of a person to define their own goals, to } \\
\text { plan and achieve strategies to achieve goals. }\end{array}$ \\
\hline
\end{tabular}

\section{Experimental learning}

It is clear from the experimental work that the formation of the intellectual potential of students in higher education depends on the process of society development, scientific and technological, educational, information and communication, cultural, managerial, public, institutional and personal potential. 
The purpose of our experimental research is to study the development and formation of intellectual potential of students, the implementation of an elective course "Intellectual potential of the future specialist" aimed at the development and formation of intellectual potential.

The content of the discipline "Intellectual potential of the future specialist" on the topic: "Formation of intellectual potential - a guarantee of maintaining the competitiveness of the country". Students will be able to understand the scientific and theoretical basis for the formation of the national intellectual potential of students on the topic, intellectual potential is a guarantee of maintaining the competitiveness of the state.

Learns about the relationship between the concepts of competitiveness, competitive nation, spiritual personality, patriot, intellectual personality and national worldview, identity, country studies, nationalism, Kazakh studies, the meaning and significance of the concept of "Kazakh", the historical formation [3;p20].

The peculiarities of intellectual culture in the formation of the intellectual potential of the nation and the main tools of spiritual and moral education of the future specialist, the importance of Abai's concept of "Full Man" in the formation of the intellectual potential of the future specialist. Features of the program of spiritual and moral education "Self-knowledge". The creative field of intellectual personality [4; p 296].

Human capital is the core of the formation of an intellectual society. Features of intellectual culture in the formation of the intellectual potential of future professionals, national education is the basis for the formation of the intellectual potential of the university, spiritual and moral education of modern youth, aspects of educating young people as intellectuals, they are described. It is explained that it is based on the formation of moral and spiritual values of society. In addition, abstract topics were prepared for each topic.

Abstract topics:

1. The phenomenon of intellectual culture: a general description.

2. Formation of spiritual and moral values of the future specialist as the basis of the potential of the intellectual nation.

3. National education: moral and spiritual nature.

4. Spirituality is the result of a person's way of life.

5. Man is the main fruit of society.

6. The process of formation of "intellectual citizen" and its content.

Questions for self-assessment:

1. What is the importance of spiritual and moral education in the formation of the personality of the future specialist?

2. Features of the formation of the potential of the intellectual nation in the context of higher education.

3. Value orientation of modern youth.

4. The importance of building the intellectual potential of the future specialist as a representative of the intellectual nation.

5. What is intellectual culture?

6. What is the role of spirituality in the development of society?

7. What are the main components of the concept of "spirituality"?

On the topic "Information society and need to develop the intellectual potential of the individual" the importance of the development of the intellectual potential of the individual in society, the creative and intellectual potential of the individual, continuing professional education - the main tool for developing the intellectual potential of the individual. comment is given. The information competence and culture of the specialist, the main components of the intellectual potential of the future 
specialist, the main elements of the system of intellectual potential development of the specialist and the state policy of informatization of the education system in the Republic of Kazakhstan.

\section{Learning space and learning outcomes}

Experimental work with students on the above topics includes brainstorming, heuristic conversation, the method of debate, the method of "business game", etc. Cognition - contributes to the development of thinking, the ability of a person as a set of mental abilities, behavioral characteristics in solving problems and the success of any action, the development of personal qualities and other abilities.

Students of Kh.Dosmukhamedov Atyrau University, specialty 5B011900“Foreign language: two foreign languages" took part in the experimental work.

The experiment consists of two stages:

During the defining experiment, the level of development of intellectual potential of university students, the quality of education, motivation, creative development of students, indicators of the development of intellectual potential of students, the number of students in the experimental group and control group were determined.

An elective course aimed at developing the intellectual potential of students who participated in the experimental work during the formative experiment will be implemented in the future, the analysis, processing, systematization and discussion of the data obtained.

\section{Conclusion}

The issue of formation of intellectual potential of the future specialist is the main one today. The integration of the national education system into the world education system, the transition of universities to the credit system can be seen in the quality of education. The fact that students choose the subject they want and the professor who teaches it is also a sign of transparency in the education system.

The main idea of the national project was identified during the study, which is related to the education of a new generation of citizens and bringing the country's competitive human capital to the level of an established state.

The importance of the continuing system education, the professional development of the future specialist in the formation of a competitive intellectual personality, the preservation of independence and country, the organization of harmony and unity in society, the formation of an intelligent society lies in the professional competence, knowledge and skills of the future specialist.

\section{ЖОО СТУДЕНТТЕРІНІН ИНТЕЛЛЕКТУАЛДЫ ӘЛЕУЕТІН КАЛЫПТАСТЫРУ, ДАМЫТУ}

Бұл мақала ұлттық құндылықтарды нығайту үшін басты міндет-үздіксіз білім беруді жаңашылдау, ақпараттандыру, білім беруді одан әрі дамыту, зияткерлікті дамыту, қалыптастыру жөнінде болып отыр.

Ұлттың интеллектуалды әлеуетін қалыптастыру мәселесі кеңінен зерттелген,қаралған, негізгі индикаторлары көрсетілген.

Қазіргі заман талабына сай бәсекеге қабілетті тұлғаның қалыптасуы-еліміздің экономикалық, әлеуметтік, саяси өркендеуімен бірге келеді.

Ақпараттық технологиялар қарқынды дамуда, білім беруге деген көзқарас өзгеруде, әлем өзгерді. Бүгінгі білім беруге деген көзқарас жаңартылған және әлі де жаңарту мәселесі негізгі орында. Білім беру жүйесі тек қана оқыту емес, бұл жеке тұлғаның адам болып қалыптасуына, дамуына ықпалдылығы мол қоғамдық құбылыс ретінде қарастырамыз.

Мектеп пен жоғары оқу орнын бітіруші түлектердің білім сапасын жақсарту мәселесі бүгінгі күннің ең негізгі сатысында. Жеке тұлғаның дамуы, қоршаған ортаға бейімделуі - оның қазіргі таңда болып жатқан экономикалық дағдарыс, өзгерістермен қатарласып, бәсекеге қабілетті тұлға ретінде осы қоршаған ортада 
қалануы - міне, басты міндет. Сол себепті, еліміздің білім берудегі салалар құрылымдарын жаңашылдау қазіргі қоғамымыздың өркениетті дамуын қамтамасыз ететін басты тетік екенін білеміз.

Қазақстанның бәсекеге қабілеттілігін қамтамасыз ететін білім берудің барлық құрылымын жаңарту қазіргі қоғамның өркениетті дамуын қамтамасыз етудің басты тетігі болып табылады.

Білім беру жүйесі - бұл тек педагогикалық категория ғана емес, сонымен қатар адами капиталды дамытуға орасан зор әсер ететін әлеуметтік құбылыс.

Негізгі сөздер: интеллектуалды ұлт, мәңгілік ел,жеке тұлға, модернизация, зияткерлік әлеует.

\section{ФОРМИРОВАНИЕ И РАЗВИТИЕ ИНТЕЛЛЕКТУАЛЬНОГО ПОТЕНЦИАЛА СТУДЕНТОВ ВЫСШЕГО ОБРАЗОВАНИЯ}

Эта статья посвящена главной задаче для укрепления национальных ценностей-инновациям непрерывного образования, информатизации, дальнейшему развитию образования, развитию интеллекта, формированию.

Широко исследована, рассмотрена проблема формирования интеллектуального потенциала нации, обозначены основные индикаторы.

Формирование конкурентоспособной личности, отвечающей современным требованиям, сопровождается экономическим, социальным, политическим процветанием страны.

Стремительно развиваются информационные технологии, меняется отношение к былинам, меняется мир. Сегодня отношение к образованию обновлено, и по-прежнему вопрос обновления стоит на первом месте. Система образования - это не только обучение, это общественное явление, способствующее становлению, развитию личности как личности.

Проблема повышения качества образования выпускников школ и вузов сегодня находится на самой основной стадии. Развитие личности, ее адаптация к окружающей среде-экономический кризис, который сейчас происходит, ее становление в этой среде, как конкурентоспособной личности, параллельно с переменами-вот главная задача. Поэтому мы знаем, что инновация структур отраслей в образовании страны является главным механизмом, обеспечивающим цивилизованное развитие нашего современного общества.

Модернизация всей структуры образования, обеспечивающая конкурентоспособность Казахстана, является основным механизмом обеспечения цивилизованного развития современного общества.

Система образования - это не только педагогическая категория, но и социальное явление, оказывающее огромное влияние на развитие человеческого капитала.

Ключевые слова: интеллектуальная нация, вечная страна, личность, конкурентоспособность, модернизация, интеллектуальный потенциал.

\section{References}

1 Message from the President of the Republic of Kazakhstan N. A. Nazarbayev "Kazakhstan's way-2050: common goal, common interests, common future". Almaty. 2014. p 40

2 Strategy "Kazakhstan-2050" - a new political course of the established state.Message from the President of the Republic of Kazakhstan N. A. Nazarbayev to the people of Kazakhstan. // Akikat. №1, 2013.- p.5-27.

3 National program of N. A. Nazarbayev "intellectual nation-2020". / Aikyn. 2008. p 20

4 Praliev S.Zh.,Orazbayeva F.Sh., Imanbayeva S.T., Berikkhanova A.E., Sholpankulova G.K. and other fundamentals of forming the intellectual potential of a future specialist. Training manual. - Almaty. KazNPU named after Abai. "Ulagat". 2014. - p 296

5 Imanbayeva S.T. new Kazakhstan patriotism-the key to the formation of an intellectual nation. // Pedagogy and psychology. Almaty. Kazakh National Pedagogical university named after Abai. 2013. № 4, p 10

6 Imanbayeva S.T. Ideas of forming an intellectual nation in the Messages of the President of the Republic of Kazakhstan N.A. Nazarbayev.// Bulletin of the Abai Kazakh National Pedagogical university. 2013. № 4. p 21

7 Balasagunm Zh. blessed Val. - Almaty: Zhazushy, 1986. - p 616.

8 Kambarbekova G.A. Philosophical treatises of al-Farabi. - Almaty, 1973. - 318.

\section{Information about authors:}

Saya Karabalina, Master of psychology-pedagogical sciences, Kh.Dosmukhamedov Atyrau University, Atyrau, Kazakhstan, Student avenue, 1, E-mail: s.karabalina@asu.edu.kz, Orcid. 0000-0003-4336-1968

Aliya Tleuova, Master of pedagogical sciences, Kh.Dosmukhamedov Atyrau University, Atyrau, Kazakhstan, Student avenue, 1, E-mail: a.tleuova@ asu.edu.kz, Orcid. 0000-0002-3054-491X 